\title{
Future fertility trends are shaped at the intersection of gender and social stratification
}

\author{
Trude Lappegård ${ }^{1, *}$
}

In this contribution, I argue that future fertility trends will depend on how fertility behavior develops at the intersection of gender and social stratification. Three trends in fertility behavior point to the interaction of gender and stratification. First, men's and women's fertility trajectories differ across the life course, and more men than women remain childless. Although an increasing number of fertility studies have focused on men, there is still far less research on male than female fertility. A recent study from the Nordic countries based on high-quality register data has shown that levels of childlessness are higher among men than among women, with the overall gender difference in ultimate childlessness remaining relatively stable at around 6-10 percentage points across cohorts (Jalovaara et al. 2019). Higher levels of childlessness among women typically predict lower overall levels of fertility (Sobotka 2017). At this point, there is no clear answer to the question of why more men than women stay childless, or of how a gender gap in fertility trajectories will influence future fertility trends.

Second, over the last decade, an unexpected reversal of fertility trends is emerging in the Nordic countries. From 2010 to 2019, the total fertility rate declined from 1.90 to 1.35 in Finland and from 1.96 to 1.53 in Norway. During the 1990s and 2000s, the Nordic countries were viewed as "best practice" societies with relatively high fertility levels and high levels of female employment. As forerunners in implementing work-life balance policies designed to make female employment and family care more compatible, these countries were able to maintain fertility at nearreplacement levels. Third, new social inequalities in fertility have emerged. The social gradient of female fertility in the Nordic countries has changed rapidly in recent years, turning into a pattern that increasingly resembles the male pattern of social inequality in fertility behavior. Levels of childlessness are now highest among low educated women as well as among low educated men (Jalovaara et al. 2019). As this new pattern first emerged in cohorts in which a significant proportion still had low education, it cannot simply be considered a selectivity effect. There is, for

\footnotetext{
${ }^{1}$ Department of Sociology and Human Geography, University of Oslo, Norway

${ }^{*}$ Correspondence to: Trude Lappegård, trude.lappegard@sosgeo.uio.no
} 
example, new evidence for Australia that fertility has declined more among low educated than highly educated women in recent years, even though low educated women continue to have higher fertility than highly educated women (McDonald and Moyle 2019).

To date, demographic theory has not provided an adequate explanation for the aforementioned trends at the intersection of gender and social stratification. Mason (1997) distinguished two gender systems: one that generates gender (in)equality at the macro level, and another that generates gender (in)equality at the micro level. At the macro level, gender inequality is measured in terms of economic, social, and political opportunities and outcomes; while at the micro level, gender inequality is defined in terms of the gender division of labor within households; i.e., time spent on paid and unpaid work (Mills 2010). From this distinction, two questions emerge: how do people in different social strata respond to gender equality at the societal level; and, how do they act on new gender roles? In particular, the surprising fall in fertility levels observed during the last decade in the Nordic countries - which are characterized by high levels of gender equality and highly developed policies aimed at enabling work-life reconciliation - raises crucial questions about the true nature of the relationship between gender equality and fertility.

Defining gender dynamics as fundamental to fertility, Goldscheider et al. (2015) attributed low fertility levels to the gender revolution that has been occurring in modern societies. They argued that a gender revolution is comprised of two stages. In the first stage, women enter the public sphere; i.e., the labor market and the political arena. In the second stage, which tends to lag behind changes in women's behavior, men take on more responsibilities in the private sphere; i.e., the family. So far, no country has completed either of the two stages of the gender revolution, whereby men and women participate equally in either the public or the private sphere. However, some countries are at relatively advanced stages in these transitions. The two components of the gender revolution are indeed related. While women's employment encourages men to become more involved in the home, it is a weak relationship, as the pace at which men have become more involved at home has not been as rapid as the speed at which women's employment has increased (Frejka et al. 2018).

Low fertility is seen as a response to the gender gap in the workload that can appear when women increase their labor force participation. This trend is expected to reverse and fertility levels are expected to increase somewhat when men become more involved in the home, and the gender workload gap diminishes (Goldscheider et al. 2015; Esping-Andersen and Billari 2015). A forerunner to these theoretical arguments, gender equity theory, predicts that societies with institutional arrangements that facilitate combining work and family life, and that have higher levels of gender equality across public and private institutions, will have higher fertility (McDonald 2000, 2006). Key evidence for the gender revolution prediction that greater gender equality leads to higher fertility is the turnaround in the macrolevel relationship between female labor market participation and fertility, whereby countries with the highest levels of female employment have the highest fertility 
levels (e.g., Luci-Greulich and Thévenon 2013; Sobotka et al. 2011). As the gender revolution is still ongoing, we do not know the full consequences of changing gender roles within the public or the private sphere. However, the sharp decline in fertility levels in the Nordic countries has called into question the positive association between gender equality and fertility at both the macro and the micro level. Gender equality must be considered in the context of a changing economy, globalization, and increasing economic uncertainty. Thus, to fully explain the new fertility trends, gender equality must be linked to systems of social stratification.

In response to the ongoing gender revolution and the formation of new gender roles, the transition to adulthood may emerge quite differently in different social strata. As we noted above, in the past, childlessness was associated with social stratification in such a way that childless men dominated at the bottom of the social hierarchy, whereas childless women dominated at the top of the social hierarchy (Andersson et al. 2009; Lappegård et al. 2011). These patterns were thought to arise from gender inequality: i.e., when men are the main economic providers, those at the bottom of the hierarchy are not considered as attractive as potential fathers; whereas when women have successful careers, they face higher opportunity costs of having children than other women (Becker 1991). However, these interpretations are based on fertility patterns that no longer hold among the younger generations, especially in the Nordic countries. Moreover, they are based on assumptions about gender inequality in the domestic division of labor and employment rates.

Although it has been heavily debated, the question of whether gender equality plays a positive role in supporting higher fertility has yet to be resolved. To understand how gender equality affects fertility in the face of economic change, we first need to examine how different socioeconomic groups respond to different institutional contexts, and whether these groups benefit from social policies in the same ways. To date, most gender theories have assumed that gender equality tends to equalize differences in fertility across social groups. For example, gender equity theory predicts that higher levels of gender equity will result in fertility levels becoming more similar across social strata (McDonald 2013). As new social inequalities in fertility are emerging, the following question arises: namely, whether highly educated middle-class families following the dual breadwinner model might be better off in the Nordic policy context than members of other socioeconomic groups. Low educated women may face higher opportunity costs of having children than highly educated women; costs that are not alleviated through social policies (Jalovaara et al. 2019). Although highly educated women suffer the largest absolute earnings losses when having a child (Evertsson 2016; England et al. 2016), their income might still be (more than) sufficient to maintain their standard of living. The comparatively small earnings losses low educated women experience when they have a child might nonetheless make it difficult for them to make ends meet (Jalovaara et al. 2019).

Another question that arises in this context is how the gender revolution has changed the partnership formation process for different socioeconomic groups. The new gender imbalance in education - whereby larger proportions of women than 
men are now acquiring higher education - is not compatible with the traditional pattern of union formation (in which women tend to "marry up" by choosing a male partner whose educational attainment is higher than their own). On the one hand, this imbalance may create a new kind of "mating squeeze" that could have consequences for union formation and mate selection (Van Bavel 2012). Thus, it is possible that an increasing number of individuals - especially lower educated men and higher educated women - may end up being unable to find a suitable partner (Van Bavel 2012). On the other hand, this imbalance may create new pathways into union formation. For example, it appears that highly educated women are increasingly forming relationships with less educated men (Chudnovskaya and Kashyap 2019). Cherlin (2016) has argued that as the gender revolution continues, both men and women are increasingly searching for a partner with both good earning potential and egalitarian attitudes. Given these trends, finding a partner and establishing a long-term relationship is likely to be especially difficult for both men and women with low education. If this is the case, rising levels of gender equality may generate fewer opportunities for union formation and childbearing among both low educated men and low educated women. Finally, we can look at how different groups at the intersection of gender and social stratification respond to globalization and changing economic conditions. Compared with their highly educated counterparts, young adults with low education face additional obstacles when trying to become a stable earner, as they are more likely to be negatively affected by increasing globalization and the automation of production in a labor market in which temporary contracts and irregular work are becoming more and more common (Mills and Blossfeld 2013). Given the new gender roles that are emerging, increasing economic uncertainty and structural changes in the labor market may mean that both low educated men and low educated women have fewer labor market opportunities than they did in the past, and that they are altering their fertility behavior accordingly.

For these reasons, I have argued that future fertility trends depend on how fertility behavior develops at the intersection of gender and social stratification. This view is based on trends in fertility behavior, such as the gender gap in fertility trajectories, the surprising and strong reversal of fertility trends in the Nordic countries, and the appearance of new social inequalities in fertility. My prediction for future fertility trends is that social stratification will play a larger role than gender in the decision to have children. Because both men and women with low education and poor job prospects will face the most constraints, they will be more inclined than their better educated, higher income counterparts to postpone parenthood and to have fewer children. It is likely that in many countries, these trends will result in lower overall fertility levels. Future research on these new fertility trends should link the two systems of gender equality and social stratification, and investigate how the interactions between them operate depending on the institutional context, changes in the economy, and globalization. 


\section{Acknowledgements}

This article was supported by the Research Council of Norway, and is part of the project "Falling Fertility and Rising Social Inequalities". I am grateful for the comments and support I received from Elizabeth Thomson, Axel Peter Kristensen, and Tomáš Sobotka.

\section{References}

Andersson, G., M. Rønsen, L. B. Knudsen, T. Lappegård, G. Neyer, K. Skrede, K. Teschner and A. Vikat 2009. Cohort fertility patterns in the Nordic countries. Demographic Research 20: 313-352. https://doi.org/10.4054/DemRes.2009.20.14.

Becker, G. S. 1991. A treatise on the family. Harvard University Press.

Cherlin, A. J. 2016. A happy ending to a half-century of family change? Population and Development Review 42(1): 121-129. https://doi.org/10.1111/j.1728-4457.2016.00111.x.

Chudnovskaya, M. and R. Kashyap 2019. Is the end of educational hypergamy the end of status hypergamy? Evidence from Sweden. European Sociological Review. https://doi.org/10.1093/esr/jcz065.

England, P., J. Bearak, M. J. Budig and M. J. Hodges 2016. Do highly paid, highly skilled women experience the largest motherhood penalty? American Sociological Review 81(6): 1161-1189. https://doi.org/10.1177/0003122416673598.

Esping-Andersen, G. and F. C. Billari 2015. Re-theorizing family demographics. Population and Development Review 41(1): 1-31. https://doi.org/10.1111/j.1728-4457.2015.00024.x.

Evertsson, M. 2016. Parental leave and careers: Women's and men's wages after parental leave in Sweden. Advances in Life Course Research 29: 26-40. https://doi.org/10.1016/j. alcr.2016.02.002.

Frejka, T., F. Goldscheider and T. Lappegård 2018. The two-part gender revolution, women's second shift and changing cohort fertility. Comparative Population Studies 43: 99-130. http://www.comparativepopulationstudies.de/index.php/CPoS/article/view/305.

Goldscheider, F., E. Bernhardt and T. Lappegård 2015. The gender revolution: A framework for understanding changing family and demographic behavior. Population and Development Review 41(2): 207-239. https://doi.org/10.1111/j.1728-4457.2015.00045.x.

Jalovaara, M., G. Neyer, G. Andersson, J. Dahlberg, L. Dommermuth, P. Fallesen and T. Lappegård 2019. Education, gender, and cohort fertility in the Nordic countries. European Journal of Population 35(3): 563-586. https://doi.org/10.1007/s10680-0189492-2.

Lappegård, T., M. Rønsen and K. Skrede 2011. Fatherhood and fertility. Fathering. A Journal of Theory, Research, and Practice About Men as Fathers 9: 103-120. https://www.researchgate.net/publication/270190595_Fatherhood_and_Fertility (23 June 2020).

Luci-Greulich, A. and O. Thévenon 2013. The impact of family policies on fertility trends in developed countries. European Journal of Population/Revue Européenne de Démographie 29(4): 387-416. https://doi.org/10.1007/s10680-013-9295-4. 
Mason, K. O. 1997. Gender and demographic change: What do we know? In: The continuing demographic transition, 158-182. Oxford University Press.

McDonald, P. 2000. Gender equity in theories of fertility transition. Population and Development Review 26(3): 427-439. https://doi.org/10.1111/j.1728-4457.2000.00427.x.

McDonald, P. 2006. Low fertility and the state: The efficacy of policy. Population and Development Review 32(3): 485-510. https://doi.org/10.1111/j.1728-4457.2006.00134.x.

McDonald, P. 2013. Societal foundations for explaining low fertility: Gender equity. Demographic Research 28: 981-994. https://doi.org/10.4054/DemRes.2013.28.34.

McDonald, P. and H. Moyle 2019. In Australia fertility is falling only for low educated women. N-IUSSP.ORG. http://www.niussp.org/article/in-australia-fertility-is-fallingonly-for-low-educated-womenen-australie-la-fecondite-baisse-uniquement-chez-lesfemmes-peu-scolarisees/\#more-3725.

Mills, M. 2010. Gender roles, gender (in)equality and fertility: An empirical test of five gender equity indices. Canadian Studies in Population 37(3-4): 445-474. https://doi.org/ 10.25336/P6131Q.

Mills, M. and H.-P. Blossfeld 2013. The second demographic transition meets globalization: A comprehensive theory to understand changes in family formation in an era of rising uncertainty. In: Negotiating the life course: Stability and change in life pathways, eds A. Evans and J. Baxter, 9-33. Springer Netherlands. https://doi.org/10.1007/978-90-4818912-0_2.

Sobotka, T. 2017. Childlessness in Europe: Reconstructing long-term trends among women born in 1900-1972. In: Childlessness in Europe: Contexts, causes, and consequences, eds M. Kreyenfeld and D. Konietzka, 17-53. Springer International Publishing. https://doi.org/10.1007/978-3-319-44667-7_2.

Sobotka, T., V. Skirbekk and D. Philipov 2011. Economic recession and fertility in the developed world. Population and Development Review 37(2): 267-306. https://doi.org/10. 1111/j.1728-4457.2011.00411.x.

Van Bavel, J. 2012. The reversal of gender inequality in education, union formation and fertility in Europe. Vienna Yearbook of Population Research 10: 127-154. https://doi.org/ $10.1553 /$ populationyearbook2012s 127.

Open Access This article is published under the terms of the Creative Commons Attribution 4.0 International License (https://creativecommons.org/licenses/by/4.0/) that allows the sharing, use and adaptation in any medium, provided that the user gives appropriate credit, provides a link to the license, and indicates if changes were made. 